\title{
急勾配リーフ地形における砕波現象と 実務に向けた位相平均型波浪変形モデル
}

\author{
Wave breaking on the reef with steep forereef slope \\ and wave deformation model based on energy balance equation
}

\begin{abstract}
関本恒浩 $^{1} \cdot$ 中嶋さやか ${ }^{2} \cdot$ 片山裕之 $^{3} \cdot$ 高橋研也 $^{4}$
Tsunehiro SEKIMOTO, Sayaka NAKAJIMA, Hiroyuki KATAYAMA and Kenya TAKAHASHI

Hydraulic model tests of wave deformation on the reef with steep forereef slope by using irregular waves were conducted. Two types of the reef topography were inspected. It is confirmed that wave deformation near the reef has very strong nonlinearity near the reef edge. Hydraulic jump at the wave front in times of buckrush and wave breaking in times of uprush coexist at the reef edge. Numerical model based on wave energy balance model developed by Takayama et al. (1991) was modified in order to estimate extreme wave condition inside and outside the reef. The comparison of the numerical simulation result with the experimental one demonstrates that Takayama's model improved in this study provides very good agreement with the experimental data.
\end{abstract}

\section{1. はじめに}

リーフ地形に代表される急勾配斜面を有する地形に波 浪が入射する場合, 砕波を含む非常に非線形性の強い現 象がみられる（佐藤ら，1985；津嘉山ら，1989）。特に 設計波のような非常に大きな波浪がリーフ上に入射する 際には,リーフエッジの干出など極めて非線形性の強い 波浪場となっており（例えば，中嶋ら，2011），数值波動 水路のような高精度波浪場解析法であっても，このよう な現象を精度よく評価することは難しい。 また，ステッ プ地形に近いリーフ地形においては, ブシネスク方程式 では減衰定常波が考慮できないため，このような地形へ の適用には理論的に問題がある。一方，波をエネルギー 表示した場合，かなり非線形性が強い領域でも，線形理 論に基づくエネルギー評価によって精度よくエネルギー の変化を評価できることが知られている（Dibajiniaら， 1988). したがって，リーフ斜面からの反射波の考慮はで きないものの, 位相平均モデルであるエネルギー平衡方 程式を用い, 適切に砕波変形を考慮することによって, 設計波級の波浪変形に対し計算精度を確保しつつ実務に 耐え得る計算が可能であることが期待できる.

本研究では, 岸側にリーフを有する急勾配地形を対象 に, 不規則波を用いた基本的な断面波浪変形実験を実施 し, リーフエッジ周辺の砕波現象に対し, エネルギー平 衡方程式を基本とした既往の研究成果を修正・援用した 波浪変形評価モデルを提案するものである.

$\begin{array}{llll}1 & \text { フェロー } & \text { 博(工) } & \text { 五洋建設 (株) 技術研究所 } \\ 2 & \text { 正会員 } & \text { 修(農) } & \text { 五洋建設(株) 技術研究所 } \\ 3 & \text { フェロー } & \text { 博(工) } & \text { 五洋建設(株) 技術研究所 }\end{array}$

3 フェロー 博(工) 五洋建設 (株) 技術研究所

4 フェロー 修(工) 五洋建設(株)技術研究所

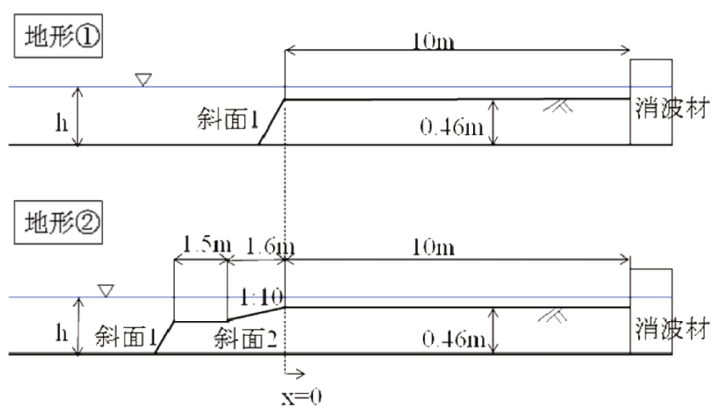

図-1 実験に用いたリーフ地形

表-1 地形条件

\begin{tabular}{|c|c|c|c|c|c|}
\hline 地形 & 斜面 1 & 斜面2 & \multicolumn{3}{|c|}{ 一様水深部地盤高 $(\mathrm{cm})$} \\
\hline 地形(1) & \multirow{2}{*}{$\begin{array}{c}1: 0.5 \\
1: 1 \\
1: 3\end{array}$} & - & \multirow{2}{*}{-50.0} & - & \multirow{2}{*}{-4.0} \\
\hline 地形(2) & & $1: 10$ & & -20.0 & \\
\hline
\end{tabular}

\section{2. 水理模型実験}

\section{（1）実験概要}

リーフ地形を用いた水理模型実験を二次元断面水槽 (長さ $50 \mathrm{~m}$, 幅 $0.6 \mathrm{~m}$, 高さ $1.2 \mathrm{~m}$ ) にて実施した. 対象と したリーフ地形は中嶋ら(2011)と同様に，一段リーフ地 形（地形(1)）と二段リーフ地形（地形(2)）の2種類とし た。図-1に実験に用いたリーフ地形の断面図を示す。沖 側の一様水深部から続く斜面 1 の勾配を $1: 0.5,1: 1,1: 3$ の3種類とした。また，地形(2)の二段リーフの場合，岸 側の一様水深部に続く斜面 2 は実験を通して $1: 10$ 勾配に

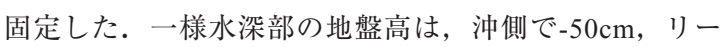
フ上で-4cm, 地形(2)場合斜面 1 と斜面 2 の間に位置す 
表-2 実験条件

\begin{tabular}{|c|c|c|c|c|}
\hline $\begin{array}{l}\text { 水深 } \\
(\mathrm{cm})\end{array}$ & $\begin{array}{l}\text { リーフ上 } \\
\text { 水深 }(\mathrm{cm})\end{array}$ & $\begin{array}{l}\text { 潮位 } \\
(\mathrm{cm})\end{array}$ & $\begin{array}{c}\text { 有義波高 } \\
(\mathrm{cm})\end{array}$ & $\begin{array}{c}\text { 有義波周期 } \\
\text { (s) }\end{array}$ \\
\hline \multirow{5}{*}{50.0} & \multirow{5}{*}{4.0} & \multirow{5}{*}{$\begin{array}{ll}+0.0 & \text { (L.W.L. }) \\
+3.0 & \text { (H.W.L. })\end{array}$} & 2.0 & 1.0 \\
\hline & & & 4.5 & 1.3 \\
\hline & & & \multirow{3}{*}{12.0} & 1.4 \\
\hline & & & & 1.6 \\
\hline & & & & 1.8 \\
\hline
\end{tabular}

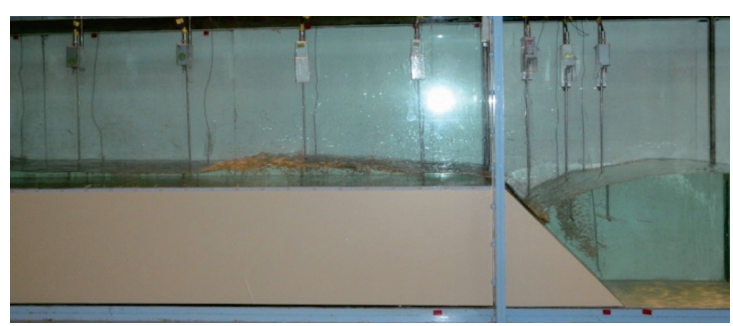

写真-1 実験状況

(地形(1), 勾配 $1: 1, H_{1 / 3}=12 \mathrm{~cm}, T_{1 / 3}=1.6 \mathrm{~s}$, L.W.L)

る一様水深部の地盤高は- $20 \mathrm{~cm}$ とした。 なお，表- 1 に地 形盤条件をまとめた。

実験ではリーフ周辺の水位変動を容量式波高計を用い て計測した。容量式波高計の配置も，中嶋ら(2011)と同 様であり，斜面 1 の法尻より約 1 波長沖に 3 本，リーフ上 に $50 \mathrm{~cm}$ の間隔で 18 本設置した。 また，斜面 1 と斜面 2 に はそれぞれ法尻と法肩および斜面上に斜面を 3 等分する 場所 2 か所に容量式波高計を設置するとともに，地形(2) では, 斜面 1 と斜面 2 で挟まれる一様水深部にも 3 本の容 量式波高計を配置した。

表-2に実験条件を示す。模型縮尺は $1 / 100$ 程度を考え， 潮位をL.W.L. $(+0.0 \mathrm{~cm})$ と H.W.L. $(+3.0 \mathrm{~cm})$ の2ケース とし，それぞれBretschneider-光易型スペクトルを有する 5 種類の不規則波を用いた。

\section{(2) 実験結果}

水理模型実験により急勾配斜面を有するリーフ地形周 辺の不規則波の波浪変形は，以下のような現象であるこ とが明らかとなった。

外洋における設計波クラスの波のように非常に大きな 波浪がリーフ上に入射する際には，引き波時には，リー フエッジが干出に近い状態になり, 波の谷に伴う沖向き 流れが斜面により強化されフロント部分に跳水現象が生 じる。引き波時にフロント部で生じた跳水による渦が押 し波時に岸側に運ばれるとともに，波自体が砕波により 強い渦を発生させ，この渦と跳水による渦とが重畳した. このようにリーフエッジ周辺では非常に非線形性の強い 波浪場となることを確認した。 写真-1 は不規則波群中の 波高の大きな波が急勾配斜面に入射する様子を示したも のであり，引き波として作用している例を示したもので

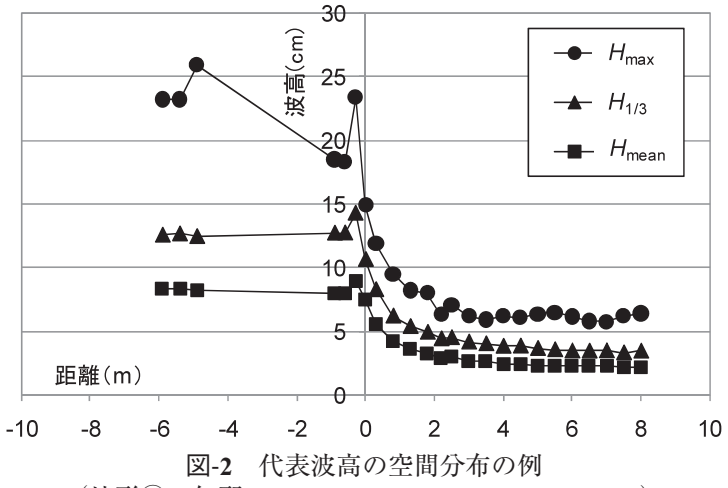

(地形(1), 勾配 1:3, $H_{1 / 3}=12 \mathrm{~cm}, T_{1 / 3}=1.6 \mathrm{~s}$, H.W.L.)

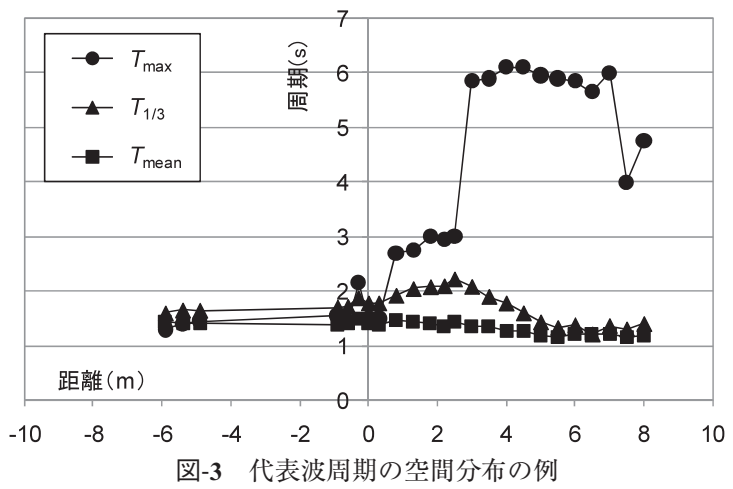

（地形(1)，勾配 1:3， $H_{1 / 3}=12 \mathrm{~cm}, T_{1 / 3}=1.6 \mathrm{~s}$, H.W.L.)

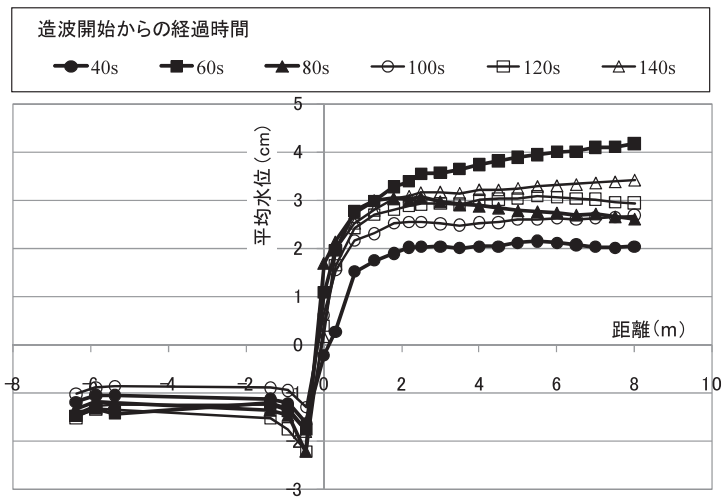

図-4 平均水位の空間分布の例

(地形 (1), 勾配 1:3, $H_{1 / 3}=12 \mathrm{~cm}, T_{1 / 3}=1.6 \mathrm{~s}$, H.W.L.)

ある。フロント部分には斜面からの波の谷に伴う沖向き 流れによって跳水が発生し, 激しく気泡が発生している 様子がわかる.

不規則波の代表波高（最高波高 $H_{\max }$, 有義波高 $H_{1 / 3}$, 平均波高 $H_{\text {mean }}$ ）の空間分布を図-2に，代表波周期（最高 波周期 $T_{\text {max }}$, 有義波周期 $T_{1 / 3}$, 平均周期 $T_{\text {mean }}$ ）の空間分布 を図-3に示す。リーフ周辺の波浪変形において代表波高 に極端な空間的変動は見られず最高波高も含め安定した 波浪統計量が得られた。代表波周期については, 最高波 


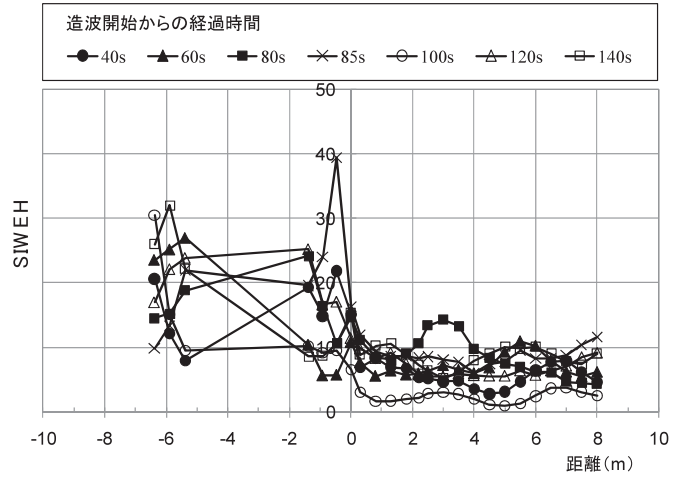

図-5 SIWEHの空間分布の例

(地形(1), 勾配 1:3, $H_{1 / 3}=12 \mathrm{~cm}, T_{1 / 3}=1.6 \mathrm{~s}$, H.W.L.)

周期が長周期波の影響を受けて変動が大きくなっている が，それ以外については比較的安定していた。リーフ上 ではリーフエッジから概ね 1 波長程度で砕波は完了する が，中嶋ら（2011）が規則波実験で示した，波の分裂に 起因するリーフエッジから 2 波長程度の区間における周 期の特徵的な空間変化は見られなかった。すなわち，波 の分裂については波の不規則性のためあまり顕著とはな らなかった。

図-4に波群のスケールより長い平均水位の空間分布を 示す.リーフ延長が $10 \mathrm{~m}$ と長かったことから，リーフ上 の平均水位が安定するまでに数波群程度の時間を要する が，それ以降は時間的・空間的に比較的安定していた。 SIWEH (Smoothed Instantaneous Wave Energy History ; 例 えば間瀬ら，1985）の時間空間分布を図-5に示す。リー フ上に着目すると, 波群としては時間的，空間的に変動 することがわかる. また，これに対応して波群スケール の平均水位は時間的・空間的に変動するダイナミックな 現象であると言える。このリーフ上における変動は, 長 周期波成分に起因するものと考えられる.

\section{3. エネルギー平衡方程式による数值計算}

水理模型実験により急勾配斜面を有するリーフ地形周 辺の波浪変形は, 非常に非線形性の強い現象であること はすでに述べた，小竹ら（2010）は，数值波動水路を用 いてリーフ地形における波浪の変形を調べ, 津嘉山ら (1989)のデータと比較しているが，リーフ前面の海底勾 配が $1: 10$ と比較的緩いにもかかわらず，再現性は十分で はない.また, 平山（2007), Nowgu・Demirbilek（2008） は，ブシネスク方程式をリーフ地形に適用し，計算の妥 当性を示しているものの，これらはリーフ前面勾配が比 較的緩い条件における検討結果であり, 本研究で対象と するリーフ前面勾配が急勾配の場合は, 前述のようにブ シネスク方程式では減衰定常波を考慮できないため，ブ シネスク方程式本来の解析精度の良さによって逆に大き
な誤差を生む可能性がある，本研究ではこれらを踏まえ， 位相平均モデルであるエネルギー平衡方程式を用いて適 用性の検討を行った。

\section{（1）砕波モデル}

エネルギー平衡方程式は高山ら（1991）のモデルを用 いた。

$$
\frac{d\left(C_{g} E\right)}{d x}=-\frac{\varepsilon_{b} E C}{\delta x}
$$

ここで，Eは波のエネルギー， $C_{g}$ は波の群速度であり， $\varepsilon_{b}$ は単位時間内に砕波によって失われるエネルギーの散逸 率を表す。高山ら（1991）は，砕波後も波高はRayleigh 分布に近いと仮定し，水深に対応した砕波限界波高を超 える部分が砕波するとして, 各計算格子におけるエネル ギー散逸率を式（2）で評価した.

$$
\begin{aligned}
& \varepsilon_{b}=\frac{\left[\int_{0}^{H b i / H_{1_{3}}} P_{E}\left(H_{S}{ }^{*}\right) d H_{S}{ }^{*}-\int_{0}^{H b 0 / H_{1 / 3}} P_{E}\left(H_{S}{ }^{*}\right) d H_{S}{ }^{*}\right]}{\int_{0}^{H b i / H_{1_{3}}} P_{E}\left(H_{S}{ }^{*}\right) d H_{S}{ }^{*}} \\
& =1-\frac{\left\{1+\frac{\pi}{4}\left(\alpha H_{b 0} / H_{1 / 3}\right)^{2}\right\} \exp \left[-\frac{\pi}{4}\left(\alpha H_{b 0} / H_{1 / 3}\right)^{2}\right]}{\left\{1+\frac{\pi}{4}\left(\alpha H_{b i} / H_{1 / 3}\right)^{2}\right\} \exp \left[-\frac{\pi}{4}\left(\alpha H_{b i} / H_{1 / 3}\right)^{2}\right]} \\
& H_{S}{ }^{*}=H / H_{1 / 3} \quad, \quad \alpha=H_{1 / 3} / \bar{H}
\end{aligned}
$$

ここで， $H_{b i}$ および $H_{b o}$ は計算対象格子に入る位置および 出る位置における砕波波高であり, 次式で与えられる.

$$
\begin{aligned}
& H_{b 0}=H_{b}+\delta H_{b} / 2 \\
& H_{b i}=H_{b}-\delta H_{b} / 2
\end{aligned}
$$

なお，砕波波高 $H_{b}$ と波が $\delta_{x}$ 進む間の砕波波高の変化率 $\delta H_{b}$ は次式で表される.

$$
\begin{aligned}
& H_{b}=A L_{0}\left\{1-\exp \left[-1.5 \frac{\pi \bar{h}}{L_{0}}\left(1+15 \beta^{4 / 3}\right)\right]\right\},(\beta \geqq 0) \\
& H_{b}=A L_{0}\left\{1-\exp \left[-1.5 \frac{\pi \bar{h}}{L_{0}}\right]\right\},(\beta<0) \cdots \cdots \cdots \cdots \cdots \cdots \\
& \delta H_{b}=-1.5 \pi \beta A\left(1+15 \beta^{4 / 3}\right) \exp \left[-1.5 \frac{\pi \bar{h}}{L_{0}}\left(1+15 \beta^{4 / 3}\right)\right] \delta x, \\
& (\beta \geqq 0)
\end{aligned}
$$

$$
\delta H_{b}=0, \quad(\beta<0)
$$

ここで， $L_{0}$ は沖波波長， $\beta$ は海底勾配， $\bar{h}$ は計算格子中 央における平均水深である。

本手法は，海底勾配として計算格子位置における勾配 をとるため, 一様水深では $H_{b i}=H_{b 0}$ となり, リーフ上では 


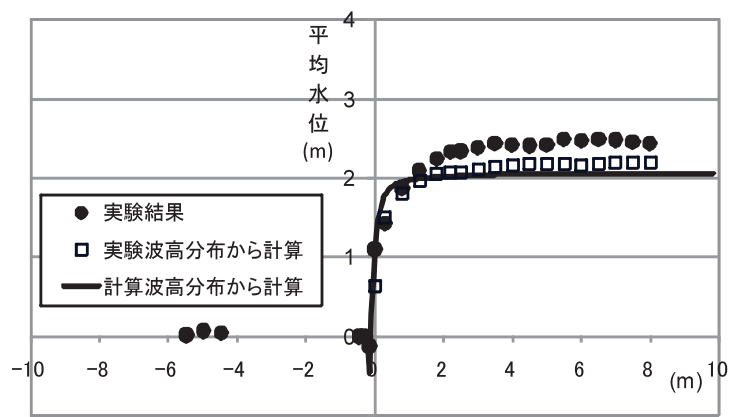

図-6 平均水位の計算值と実測值の比較

(地形(1), 勾配 1:3, $H_{1 / 3}=12 \mathrm{~cm}, T_{1 / 3}=1.6 \mathrm{~s}$, H.W.L.)

エネルギー散逸を正確に考慮することが難しい.

\section{(2) 数値計算の方法}

ここでは，二つの方法を提案する．まず，一様水深部 でも砕波に伴うエネルギーの消費が継続したのち波が再 生すること, リーフ上での水位上昇の影響が考えられる ことを考慮し, 高山ら（1991）による砕波変形モデルの 修正を提案する。高山ら（1991）らは砕波波高 $H_{b}$ を求め る際に計算対象位置における局所的な海底勾配を用いて いる. しかしながら，波の変形の水平スケールは沖波波 長で1波長程度であることから, 海底勾配として局所勾 配ではなく計算対象位置から沖側に沖波 1 波長間の平均 勾配を考えるものである. 二つ目は, 砕波後のセットア ップの影響を考慮するため, 波浪場を次に示す二段階で 評価する評価法を提案した。まず第一段階として，上記 砕波モデルによる波浪の変形計算と海浜流の数值計算に よる平均水位の変化量の評価を行う。第二段階として第 一段階で求められた平均水位の変化量を含めた水深を実 水深とみなし, 再度上記波浪変形モデルにより波浪場を 評価するものである.

\section{（3）実験結果との比較}

図-6は第一段階で計算した波高分布から求められる wave setupの計算結果を確認したものであり，実測され た波高值から同様に wave setupを計算したものも併せて 示した. 2 種類の計算結果は概致一致するものの, ケー スによって実験結果をやや過小あるいはやや過大に評価 した。ただし，ここに示した結果は，磯部ら（1988）の 計算と同程度の精度を有するものと考えられる。なお， 実験ではリーフ上でのsetupに要した水のボリュームだけ 沖側の水位が低下したため, 数值解析では初期水深から 沖側の水位低下分だけ水深を下げて計算を行った。

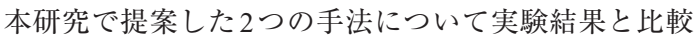
した結果を図-7および図-8に示す。また，図には高山ら の方法（1991）による計算結果も同時に示した.

高山らの方法（1991）では，局所海底勾配を用いて砕 波限界波高を評価しているため, リーフ上のような平坦
な場所では砕波減衰が見られず，実験デー夕と大きく乘 離した結果となっていることがわかる。一方，砕波波高 の評価の際に 1 波長平均の海底勾配をとったもの（本モ デル-1）とさらに平均水位の上昇の効果を考慮したもの （本モデル-2）はリーフ上でも砕波減衰による波高変化が 見られることがわかる。これらの結果を全体的にみると 水位上昇の影響を考慮しない方が実験デー夕に対する適 合度が高い。これは，津嘉山ら（1989）が指摘したリー フ上の波高は平均水位の上昇量に無関係であることに符 合する結果となった。

詳細に結果をみると1段リーフ地形の条件に対して, リーフ前面勾配が1:1よりも急な条件では, 計算はリーフ エッジに打ける波高を過小評価している。これは，リー フエッジ付近における反射波の影響と考えられる。すな わち，エネルギー平衡方程式では，斜面からの反射を考慮 できないのに対し，リーフ前面の勾配が急な場合はその影 響が顕著となったためと考えられる。このことはリーフ前 面勾配が $1: 1$ よりも急な条件では, 沖側一様水深部に扮け る波高が入射条件よりも大きくなっていることからも毫付 けられる。

リーフ上の水深が小さいケースでは, 計算值のほうが 実験值よりリーフエッジ近傍の波高隇衰が急激に生じて いることがわかる．これは，2段リーフ地形の条件でも若 干見られた。 その理由として, リーフ上の水深が浅い場 合, リーフ前面で発生した跳水による渦と砕波による渦 が重畳し，大規模な乱れとしてエネルギーが増加した可 能性が考えられる。また，このような乱れの大きい場所 では水位変動自体も正確に計測できていない可能性もあ り，波高の計測精度も含め今後詳細な検討が必要である.

しかしながら，本研究で提案した高山ら（1991）の手 法を修正する方法は, リーフ周辺の波浪変形を非常に精 度よく再現できており，上記のような解決すべき課題は あるものの，実務への適用には十分と言える.

\section{4. おわりに}

本研究では, 急勾配斜面を有するリーフ周辺の波浪変 形に関する水理模型実験を実施するとともに，高山ら （1991）の手法を修正したエネルギー平衡方程式による 波浪場評価を行った。

水理模型実験ではリーフ周辺の波浪変形は非常に複雑 であり非線形性の非常に強い現象であることが磼認でき た。このような波の場では従来計算精度が高いと言われ ている数值波動水路やブシネスク方程式などの波動を表 現する方程式系では, 現象を十分に再現できない可能性 があることを指摘した。

本研究で提案した波浪変形評価手法のうち, リーフ上 の平均水位の影響を考慮しないモデル，すなわち 1 波長 


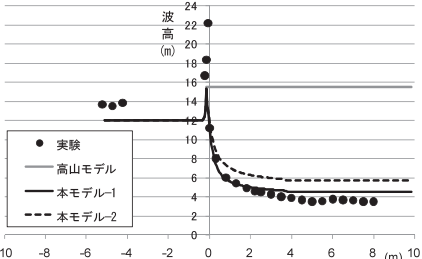

(a) 勾配 1:0.5(H.W.L.)

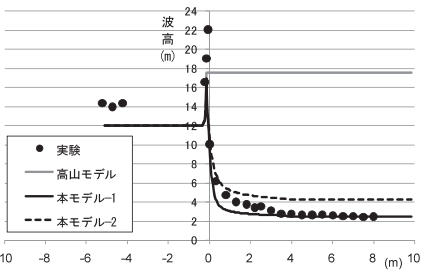

(d) 勾配 1:0.5(L.W.L.)

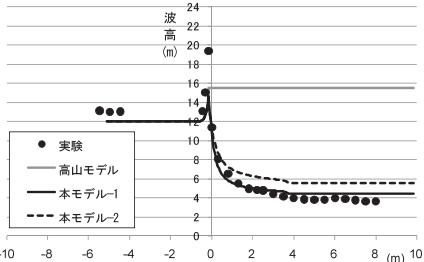

(b) 勾配 1:1(H.W.L.)

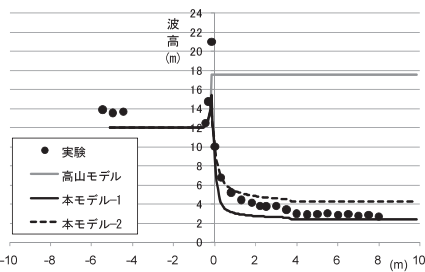

(e) 勾配 1:1(L.W.L.)

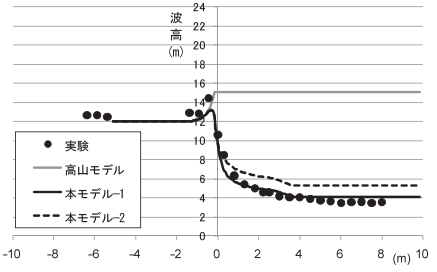

(c) 勾配 1:3(H.W.L.)

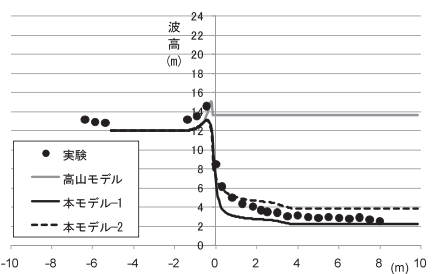

(f) 勾配 1:3(L.W.L.)

図-7 1 段リーフ地形に招ける波高分布の比較 $\left(H_{1 / 3}=12 \mathrm{~cm}, T_{1 / 3}=1.6 \mathrm{~s}\right)$

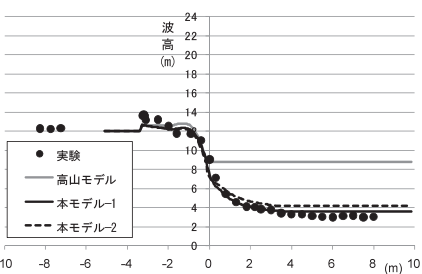

(a) 勾配 1:0.5(H.W.L.)

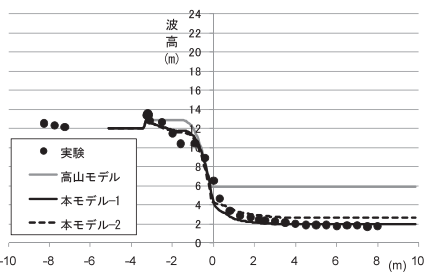

(d) 公配 1:0.5(L.W.L.)

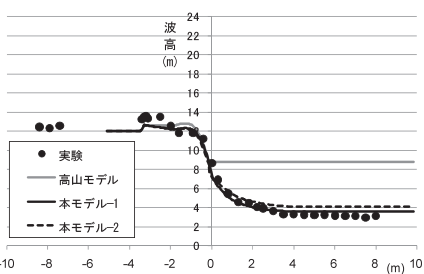

(b) 勾配 1:1(H.W.L.)

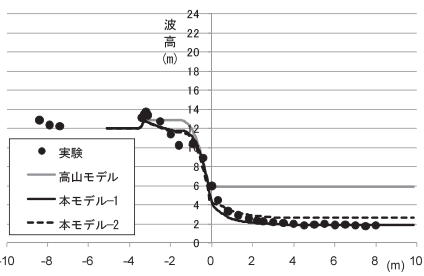

(e) 勾配 1:1(L.W.L.)

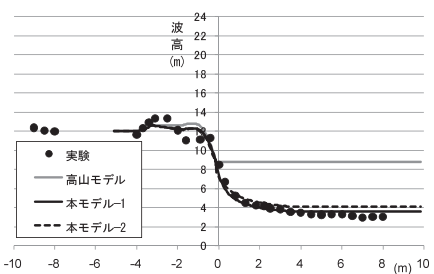

(c) 勾配 1:3(H.W.L.)

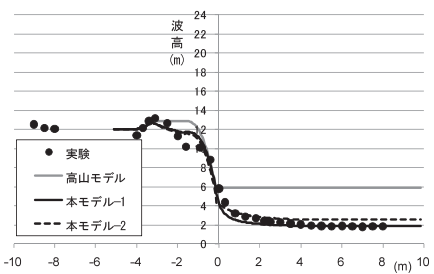

(f) 勾配 1:3(L.W.L.)

図-8 2段リーフ地形に打ける波高分布の比較 $\left(H_{1 / 3}=12 \mathrm{~cm}, T_{1 / 3}=1.6 \mathrm{~s}\right)$

程度の平均海底勾配により砕波波高を評価したモデルは リーフ周辺の波浪変形を極めて精度よく評価できること がわかった。ただし，リーフ上の水深が極めて浅い条件 ではやや計算の再現性が十分でなく今後の課題である が，本研究で提案した方法は実務上十分な計算精度を有 していると言える。

\section{参 考 文 献}

磯部雅彦・柴田洋三・泉宮尊司・渡部 晃（1988）：不規則波 によるリーフ上の平均水位上昇に関する研究，第 35 回海 岸工学講演会論文集, pp.192-196.

小竹康夫・荒木進歩・松村章子（2010）：リーフ上の波浪変形 に対する数值波動水路の適用性検討，海洋開発論文集， Vol.26, pp.321-326.

佐藤道郎・羽田好勝・中江周作・吉松秀雄（1985）：ステップ 型リーフ上での波の変形に関する実験的研究，第32回海
岸工学講演会論文集, pp.85-89.

高山知司・池田直太・平石哲也（1991）：砕波および反射を考 慮した波浪変形計算，港湾技術研究所報告，第 30 巻，第 1 号, pp.21-67.

津嘉山正光・仲座栄三・我喜屋邦浩（1989）：リーフ上の波の 変形に関する研究, 海岸工学論文集, 第 36 巻, pp.70-74.

中嶋さやか・関本恒浩・片山裕之・高橋研也 (2011) : 急勾配 リーフ地形におけるリーフ上の波の変形に関する実験的研 究, 土木学会論文集B3 (海洋開発), Vol.67, (印刷中).

平山克也（2007）：ブシネスクモデル（NOWT-PARI）を用い た高精度港内静穏度解析法の提案，港湾空港技術研究所 資料, No.1159, 90p.

間瀬 肇・古室健史・岩垣雄一（1984）：伝播に伴う Wave Group 特性の変化，第31回海岸工学講演会論文集, pp.158-162.

Dibajnia,M ・磯部雅彦・渡辺 晃（1988）：有限振幅波および 微小振幅波の浅水変形の比較, 第 43 回土木学会年次学術 講演会講演概要集第2 部, pp. 580-581.

Nwogu,O. and Z. Demirbilek(2008) : Nonlinear wave transformation and runnup over fringing coral reefs, Proc. $31^{\text {st }}$ ICCE, pp.242-254. 